\title{
TEACHER'S ROLES AS: CLASSROOM MANAGER AND CLASSROOM INSTRUCTOR
}

\author{
Rendy Oratmangun \\ Sekolah Tinggi Ilmu Ekonomi (STIE) Saumlaki, Maluku, Indonesia \\ oratmangunr@gmail.com
}

Received : 27-01-2021

Revised : 14-02-2021

Accepted : 24-02-2021

\begin{abstract}
This descriptive quantitative study was intended to analyze and describe the the respondents' perception of their teacher's two classroom roles, namely manager and instructor. This study also examined the relationship of each role and different perception based on the respondents' gender. There were 20 male students and 22 female students responded to the self-constructed questionnaire which was designed to evaluate one female English teacher. The results showed that this female English teacher was perceived as an effective English teacher who had played her roles in the classroom such a way that she was able to meet her student expectations. Next, each of the teacher's role was significantly correlated with her other roles. The teacher's two roles were found to be significantly correlated with each other. They all gave indication that when one role was played well, it would give influence on the increase of the level of other roles. These correlations implied that the teacher's teaching competencies were already integrated in one personality. Finally, the finding showed that the students perception of their female teacher's roles in the classroom had no gender bias, despite its commonality in education when perspectives are measured across opposite and same genders.
\end{abstract}

Keywords: teacher roles; classroom manager; classroom instructor; PRISMA; SPSS

\section{INTRODUCTION}

There was a situation when new students felt about the excitement of going to a new school. They might have been thinking of new situation that gave them enthusiasm, pleasure, and enjoyment. But the first day passed by and their expectation did not come to realization. Day after day they finally became accustomed to the routine activities, and there were no more excitements. Things seemed to become common and even worse and difficult for them to cope with.

In such situation, teachers need to know and realize that they have roles to play in order to overcome the difficult times their students have. Fox, Brogan, and Butler (Butler 
\& Reynolds, 2014) said that all students wanted to learn something new from their teachers, so the teachers were expected to guide and encourage students by setting the situation that lead to wilder and fuller experience. Teachers need to think about how to manage their classrooms so that they will be exciting to their students all the time. They need to think about new ways of teaching so that they will be interesting for their students to study during class hours. They should be creative in finding ways to help their students overcome problems and prepare them for their future lives. These things will get more wonderful if teachers do it in a sincere and whole heartedly way.

In line with the explanation above, the researchers were interested to look for the answers to these problems in more in-depth way. Hopefully this research will give informative and factual suggestions for the teachers of tomorrow so that they will learn some useful lessons from current teaching practices. In this way, they can better prepare themselves as to improve their teaching professionalism, particularly in regard with the English teacher's role as manager and instructor.

In general, the purposes of this study were to analyze the quantitative data in order to find a description of the English teacher's multiple roles as classroom manager and instructor. Based on the purposes stated above, the research questions of this study are formulated as follows:

1. What are the levels of the respondents' perception of their English teacher's roles as manager and instructor in the classroom?

2. Are there any significant relationships between each of the English teacher's roles in the classroom?

3. Is there any significant difference between male and female student perception of the teacher's roles as manager and instructor in classroom?

Since the beginning of time, God as our creator has given responsibility for human being to do some job that associate with human power and position. The more power or the higher position individuals have the more accountable they should be to God and other human beings. God puts in human being should to carry the burden and that is the law. Nowadays that situation never changes and every human being still has responsibility to do in order to continue human history and the law still works as well.

All things that are related to responsibility, part, function, job, or task are described by the word role. The meaning of role as explained by Lexicon Encyclopedia (1987) is "set of expectations associated with a person's position in a social organization" (p.271). It carries meaning as a rule as has been described in previous paragraph. Ginsberg and Wlodkowski (Wlodkowski \& Ginsberg, 2010) define role as "acting out a possible situation" (p.128), indicating that role depends on the situation where the person resides. The form of role is situational but the law is principle.

At the turn of the 21 stcentury changes have happened and the current community is different from the past. As a result, it creates different roles for today's teachers. The concept of teachers' roles in the previous century might not be applicable to this century. In the 19thcentury when people began to build machines, teachers played role as classroom instructor to teach their students how to construct machines without so much care of their spiritual or emotional aspects. But in this century as modern century which is full of shifts in knowledge, emotional, and spiritual aspects, the technology creates different teachers' roles. For example, when a teacher teaches or instructs students in the classroom, he or she also educates them and gives them counsel on how to solve their learning problems. Further, there is no strong reason to believe that the concepts of teacher's roles this century will be applicable in the next century.

In daily life of education, there are many situations in which the learners feel destructive psychologically, cognitively, and spiritually, as the learners enter the education world in order to study and prepare themselves for their future lives. At the time the 
learners enter into the education world, the teachers have responsibility for helping them, therefore appears what-so-called roles that teacher must play. In this case the teacher's roles may explain some of teacher's responsibilities inside the classroom or outside the classroom in order to help students to overcome every difficulty. In making a movie, a director makes sure that every actor or actress must play their roles as prescribed by the scenario. Likewise, a teacher must consider several scenarios that could help them play their roles effectively.

Knowing about teacher's role as classroom manager is very crucial, because there are several things that teacher must do when they play their role as a classroom manager in order to manage time and space; for examples, paying attention for the students' attire, hair style, attendance, etc. All the scenarios that teacher must do in playing role as classroom manager can be concluded in one keyword, that is discipline. According to Kohn (Kohn, 2006), when referring to the concept of discipline, teachers need to engage in "curriculum and a caring community" (p.118). His idea indicated that in playing this role teachers need to pay attention for curriculum, because the curriculum tells all the things that teacher must do in managing a classroom and teachers also need to relate the curriculum with community's needs; here, the community means students. In this literature review, there are literal but practical principles that teachers must do in terms of playing role as classroom manager: observing, planning, settling, directing, judicature, and giving fit treatment.

Teacher's role as classroom instructor is very important. Rondonuwu (Simanungkalit \& Rondonuwu, 2020) stated about managing instruction is referred to "teachers' ability to prepare and carry out strategic instruction in the classroom"(p. 78). His idea indicated that in doing managing instruction, teachers play the role to organize several strategies to transmit knowledge to students. It is referred to teacher as classroom instructor (Rondonuwu, 2018). The other idea why this part is important is because in teaching also could be exciting and rewarding interesting if teacher give satisfaction to help learners to learn. Arends (Arends \& Kilcher, 2010) stated why it will be rewarding and interesting because in teaching there are several "information that students are expected to learn" (p. 285). As a result, learners give positive response, but there are such things (scenario) that teacher must do in relation to pedagogical teaching and learners' positive response.

\section{RESEARCH METHODOLOGY}

This study was a survey that utilized a quantitative descriptive design. It collected information from samples that were selected form a particular population. It also involved correlaitonal analysis in order to find out whether or not there were significant relationships among the variables under study (Wallen \& Fraenkel, 2001). There were four variables of teacher's roles namely Classroom Manager and Classroom Instructor to examine the relationship among the roles.

This target population of the study was the students at Sekolah Menegah Atas (High School) or SMA of Pioneer International School Manado (SMA PRISMA). Purposive-sampling method was applied in this study wherein one particular English teacher was evaluated by her students who were in grade 11 with Science and Social Studies as their majors. The number of respondents in this study was 42 students consisting 22 female and 20 males who were presented at the moment and participated voluntary in answering the questionnaire. 
As a procedrue to collect the data for this study, the researchers took the sequential steps as follows:

1. The researchers submitted a recommendation letter from the Dean of Educaton Faculty to the principal of SMA PRISMA requesting for permission to distribute the questionnaire to the students of Grade 11 with Science and Social Study major so that the data needed for this study could be collected.

2. The researchers distributed the questionnaire to the students in every Grade 11 classroom at SMA PRISMA.

3. The researchers asked the respondents ot fill up the questionnaire honestly in accordance to their experience with the English teacher.

4. The respondents were given fifteen to twenty minutes to answer all time in the questionnaire.

5. Finally, the questionnaire were collected for data analysis and interpretation.

The questionnaire employed in this study generates quantitative data, which were analyzed statistically, using statistics software Microsoft Excel and SPSS (Statistical Package for the Social Science). And the following statistical techniques were used to analyze and interpret the data:

1. Recoding the score of each item, since each item for the questionnaire was initially designed in such a way the thighest level of satisfaction was scored as 1 and the lowest level of satisfaction was scored as 5.

2. Descriptive statistics was used to show the frequecy, mean, and standard deviation of variable under study, ranged form 1.00 to 5.00 in accordance with the 5-point likert scale.

The respondents were not burdened financially as they answered each of the items in the questionnaire given to them, expect that of the time spent in it. Before the respondents filled out the questionnaire, they were given due information regarding the instrument, procedure, and the main purpose of the study. Confidentially and volunterism were guaranteed since they were not required to write their names and they were given freedom to withdraw at the time without consequences, should they have no willingness to participate in the study. The respondents were also informed that the results of the study would not affect anything on their status as student and jeopardize their relation with their teacher under evaluation.

\section{RESULTS AND DISCUSSION}

\section{What are the levels of the respondents' perception of their English teacher's roles as manager and instructor in the classroom?}

The student respondents in this study evaluated their female English teacher's four classroom roles. It is shown in Table 1 that average scores of the student perception of her four roles were scored as follows: manager $(M=3.51)$, instructor $(M=3.79)$. The two average scores indicated that the levels of their teacher's roles were found level for role as high level for roles as manager, instructor. It all meant that overall the teacher being evaluated was considered as a teacher who had played her roles in such a way that could meet the student expectations. In other words, the 42 student respondents perceived their female English teacher as an effective English teacher who had played her roles as they expected.

\section{List 1}




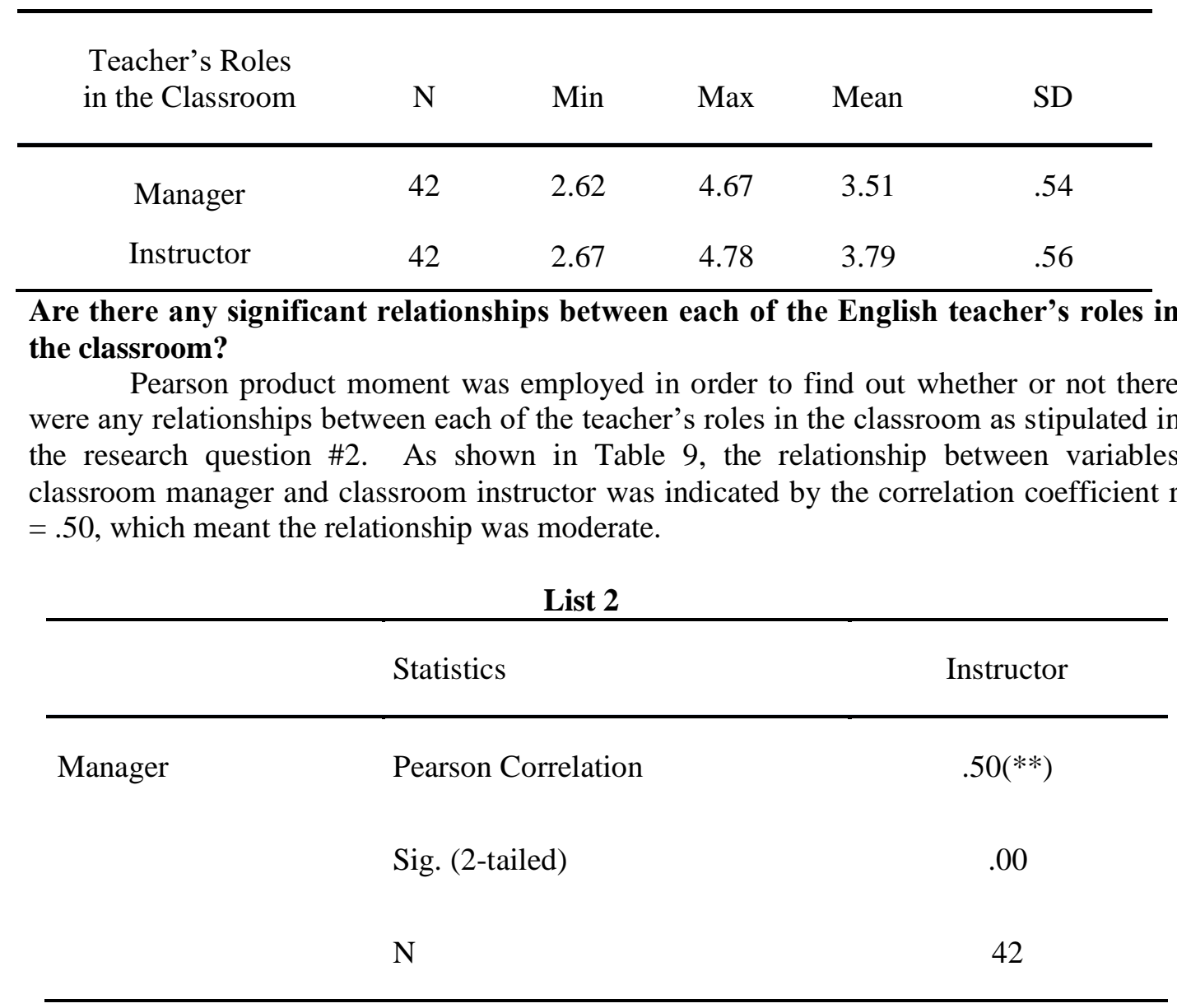

This show that there is high significant correlation between teacher as classroom manager and classroom instructor in classroom.

2. Is there any significant difference between male and female student perception of the teacher's roles as manager and instructor in the classroom?

There was a difference between the male and female student perception of their teacher's classroom roles as manager, instructor, counselor, and educator. Nevertheless, the mean scores of levels of their perception of their teacher's roles did not consistently indicate monopoly of one particular gender. The male students gave higher score for their teacher's other role, namely the classroom instructor $(\mathrm{M}=3.80)$, when compared with those of the male students who gave lower scores for their teacher's roles as manager $(\mathrm{M}=$ 3.49).

List 3

\begin{tabular}{llcc} 
Gender & Statistics & Classroom Manager & Classroom Instructor \\
\hline Male & Mean & 3.49 & 3.80 \\
& $\mathrm{~N}$ & 20 & 20 \\
& $\mathrm{SD}$ & .56 & .56 \\
Female & Mean & 3.52 & 3.78
\end{tabular}


$\mathrm{N}$

SD
.53

\section{CONCLUSION}

This descriptive quantitative study was intended to analyze and describe the relationships of each of the teacher's classroom roles and difference in the respondents' perception based on their gender. Statistical analyzes were employed by using computer software SPSS in order to find out the levels of the teacher's classroom roles and whether or not there was significance in the relationships of the teacher's roles with each other roles and in the differences in the male and female respondents' perception of their teacher's roles in the classroom.

There were 20 male student and 22 female students responded to the selfconstructed questionnaire which was designed to evaluate one female English teacher. After the data were collected through the questionnaire, they were statistically treated descriptively and inferentially. Descriptive statistics was utilized to find the mean scores of the respondents' perception of their teacher's roles in the classroom, which resulted in the description of the level of each of the teacher's roles ranging from 1 to 5 in accordance with the 5-point likert-scale in the questionnaire. Inferential statistics was utilized in order to derive conclusions whether or not the null hypotheses would be rejected.

The average scores of the student perception of their teacher's classroom roles were categorized at moderate and high levels. Therefore, it could be concluded that the 42 student respondents perceived their female English teacher as an effective English teacher. She played her roles in such a way that she was able to meet her student expectations in the classroom.

One-way ANOVA showed that the 20 male and 22 female students were not significantly different in their perception of their teacher's roles in the classroom. This finding indicated that the student perception of their female teacher's roles in the classroom had no gender bias.

By using correlational analysis of Pearson product moment, it was found that there were significant relationships between each of the teacher's roles in the classroom. The teacher's four roles were found to be significantly correlated with each other. They all gave indication that when one role was played well, it would give influence on the increase of the level of other roles. These mutual correlations implied that the teacher's roles in the classroom were holistic, wherein her teaching competencies were already integrated in one personality.

Based on the discussions and conclusions above, the researchers have come up with the following recommendations:

1) That the administration of SMA PRISMA keep and continue to empower the teacher under study as an invaluable asset of human resource, because she was able to play her roles that met her student expectations.

2) Those further similar studies are conducted with broader scope that covers item analysis or factorial analysis so as to reveal the keys to successful teaching of the teacher under study, because she was able to create a classroom in which there was no gender bias.

3) That other English teachers may learn lessons from this teacher's teaching practice by peer observation and the like so they can be benefited from the successful teaching of the teacher under study.

4) That the administration of SMA PRISMA facilitates that the teacher under study share her teaching expertise with other teachers in the school. 
5) That students who study English education can take advantage to have their teaching practicum which is supervised by the teacher under study.

\section{BIBLIOGRAPHY}

Arends, D., \& Kilcher, A. (2010). Teaching for student learning: Becoming an accomplished teacher. Routledge.

Butler, C., \& Reynolds, K. (2014). Modern children's literature: an introduction. Macmillan International Higher Education.

Kohn, A. (2006). Beyond discipline: From compliance to community. ASCD.

Rondonuwu, J. J. (2018). Student self-description of mathematical and verbal skills and mathematical and English achievements. Human Behavior, Development and Society, 17, 58-67.

Simanungkalit, A. G., \& Rondonuwu, J. J. (2020). Mentoring Style, SelfDescription, and Academic Achievement in English Class. Acuity: Journal of English Language Pedagogy, Literature and Culture, 5(1), 1-11.

Wallen, N. E., \& Fraenkel, J. R. (2001). Educational research: A guide to the process. Psychology Press.

Wlodkowski, R. J., \& Ginsberg, M. B. (2010). Teaching intensive and accelerated courses: Instruction that motivates learning. John Wiley and Sons. 